Preprints of the

Max Planck Institute for

Research on Collective Goods

Bonn 2015/2

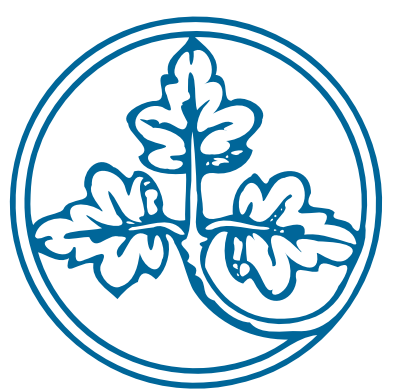

The Mutualisation of Sovereign Debt: Comparing the American Past and the European Present

Armin Steinbach

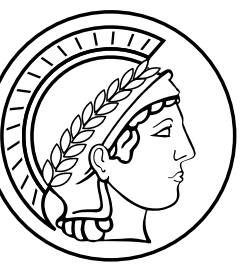




\section{The Mutualisation of Sovereign Debt:}

Comparing the American Past and the European Present

Armin Steinbach

January 2015 


\title{
The Mutualisation of Sovereign Debt: \\ Comparing the American Past and the European Present
}

\author{
January 2015
}

\section{Armin Steinbach*}

This is a preprint of an article accepted for publication in Journal of Common Market Studies.

\begin{abstract}
This study identifies commonalities between two historical incidents of debt assumption - in the United States in 1791 and in present-day Europe. By comparing the interests and behaviour of key players in these two incidents, we find three major parallels: First, in their strategic interactions, parties both for and against debt mutualisation raise arguments based on notions of fairness and morality. Second, in both historical episodes we find harsh rhetoric levelled against private creditors, who are derided as greedy speculators. Third, bargaining is an essential element of the debt assumption process. Bargaining is directed towards limiting or expanding the scope of debt assumption. Further, bargaining typically leads to some form of conditionality imposed in order to increase the chances of the debts being repaid or to ensure benefits accrue to the parties assuming the debt.
\end{abstract}

JEL-Codes: H63, F55, N11, E62

Gwilym Gibbon Fellow, Nuffield College, Oxford University and Senior Research Fellow, Max Planck Institute for Research on Collective Goods (Bonn). 
"To Fund - or not to Fund - that is the question!" - Gazette of the

United States, April 14, 1790.

"The Most Important Question in Europe: To Bailout or Not to

Bailout?" - The Atlantic, June 15, 2012.

\section{Introduction}

Debates on the sovereign debt crisis in Europe often refer to the historical experience of the United States (US). Some features of US fiscal federalism that are frequently addressed in the literature on European monetary integration for comparative purposes include: (1) the transfers taking place between the federal government and the federal states in the US (Bayoumi/Masson, 1995; Darvas, 2010)); (2) the absence of federal bailouts for states (Bordo/Markiewicz/Jonung, 2011, pp.475-508); and (3) limitations on deficits of individual states and their correspondingly low levels of public debt (Henning/Kessler, 2012). ${ }^{1}$

However, less light has been shed on the mutualisation of debt ${ }^{2}$ and the bailout of states which occurred both in the US shortly after the adoption of the Constitution in 1790, and which is also occurring in present-day Europe (an exception is EEAG, 2013, pp.95-107). The European experience over the last few years, which has seen repeated credit extension to crisisracked countries under the condition of joint and several liability of all euro area members, has clear parallels (as well as obvious differences) to the US experience in $1791{ }^{3}$ Shortly after the US Constitution replaced the much looser Articles of Confederation, Alexander Hamilton, First Secretary of the Treasury, sought to have the federal government assume the remaining revolutionary war debts of the individual states. He was successful in gaining congressional approval, but only after much controversy (Ferguson, 1961; Perkins, 1994, pp. 199;

1 Other important studies ground the establishment of EMU and the euro in the context of the history of international monetary cooperation and of monetary unions; see Bordo/James (2008) and Bordo/Jonung/Markiewcz (2011).

2 Mutualisation, for the purpose of this analysis, refers broadly to any kind of debt relief exercised by some states in favour of others. It is acknowledged that, in the technical sense, debt relief differs in the historical US and the present EU case. While in the former debts were actually being assumed by other states, in the latter debt was relieved through loans at below-market prices. The introduction of Eurobonds would follow a different logic, as they would entail government bonds that would be the liability of the eurozone in the aggregate. However, for this analysis such differences between the forms of debt mutualisation do not matter, as the political-economy features of the struggle for and against debt relief are alike.

3 A different research focus would be comparing the example of the "no bailout" policy in 1840 and the "no bailout" discussion in Europe. In the US, the no bailout principle was implemented more rigorously, accepting that some US states would be forced into default. This comparison would reach a different conclusion than a comparison with the 1790s. We focus here on the comparison with the 1790ies episode for the purpose of illustrating the driving forces behind the struggle about debt mutualisation. The pattern of conflicting interests and the ultimate agreement on some form of debt relief both in the EU and the US of the 1790ies stand in contrast to the 1840ies episode where state insolvencies were accepted. 
Ellis, 2002, pp. 48; Bolles, 1969, pp. 22; Wood, 2009, pp. 95; Sylla, 2011, pp. 59; Chernow, 2004, pp. 297; Elkins/McKitrick, 1993).

This study aims to identify commonalities between the two historical incidents of debt assumption from the perspective of political economy by comparing the evolution of stakeholders' interests and behaviour leading to debt mutualisation. More broadly, the article seeks to assess the pattern of behaviour of the actors involved in the bargaining process. To that end, we adopt a political economy perspective and use comparative tools to identify the dynamics behind the struggle on debt relief. As indicators we examine the nature of the underlying conflicting interests of the (state) actors, the patterns of argumentation for and against debt relief, the political and economic treatment of creditors and the conditionality attached to debt relief. By using comparative benchmarks we seek to gain insight on the characteristic political economy features of bargains over debt mutualisation.

Against this background, Section 2 identifies the notions of fairness and morality as a key feature in strategic interactions between opposing stakeholders. We find that arguments related to fairness and morality are made both by debtor states and authorities who assume debt as a justification either to request or reject debt assumption. States taking on debts frequently argue that their assumption of debtor states' liabilities would punish states that assume debts for their successful budget discipline as well as incentivize states to engage in poor budget discipline. The economic argument of moral hazard is implicit in these claims. Debtor states, by contrast, contend that they bear a special burden that should be shared by the community of states, as debt assumption would ultimately also benefit the fiscally sound states that take on the debt of others. Section 3 identifies the treatment of creditors as another recurring element in debt assumption debates. The role of creditors tends to be controversial, as their responsibility to be involved in debt restructuring is often discussed in moral terms. Section 4 identifies the implementation of conditionality in both historical contexts as a common outcome in the bargaining between states. Conditionality - or, rather, reciprocity in the deal refers to commitments that one party offers to obtain more favourable conditions or to make the deal possible at all. Conditionality in debt assumption has been used to minimize the scope of debt mutualisation, to increase the likelihood of debt repayment, and to secure quid pro quo commitments that may be unrelated to the debt issue.

\section{The political battle lines between debtors and debt assumers}

While there were clearly divergent causes of debt assumption in the US and the EU, ${ }^{4}$ an examination of the political economy of debt assumption in each incidence reveals similar patterns both with a view to stakeholders' positions and interests, as well as in the general dynamics of bargaining between them.

4 In the US, the War of Independence preceded the debt issue, while in the euro area the budgetary management by individual members of the eurozone was the root of the problem. For the US, see, inter alia, Sargent, 2012; for the EU, see Alessi, 2013. 
A recurring feature of debates about debt mutualisation is the opposition between entities supporting and opposing a transfer of liability. Debt assumption is an economic matter by nature, and may alleviate difficulties faced by the states that are in debt. By contrast, the entities assuming debts generally oppose this step because of the negative effects of being shouldered with greater debt and because of the unwillingness of citizens and taxpayers to bear the burden of a foreign or outside constituency, although at later stage they will be compensated.

In the US, the debate that occurred in 1790 and 1791 shows that a crucial driver of support or opposition was the economic interest of the states. States that stood to lose from assumption were against it; states that hoped to gain were in favour of it; and states whose interests were not greatly affected either way were indifferent (Ferguson (1961, 307). More specifically, the heart of the dispute was between states that had large debts remaining from the Revolutionary War and those that had already paid for them. South Carolina and Massachusetts wanted to transfer their enormous liabilities on the Union. These states expected their financial position to deteriorate as Congress imposed new taxation; they requested immediate relief on the grounds that their debts represented expenditures for a common cause and were thus rightfully chargeable to the Union. In their view, the size of their debts proved solely that they had contributed more than their share to the War of Independence (Ferguson $(1961,308)$ ).

Similarly, southern states were positive that the Union would compensate them for their expenditures on behalf of the past warfare. For them, the assumption of state debts was seen as a threat to their bargaining position on the issue of compensation. Southern delegates were fearful that the states that would benefit immediately from assumption would have a positive incentive to block an agreement in the future in which the Union would provide recompense to the states for the war. Throughout the debate, the southerners repeatedly emphasized that, while assumption would satisfy some states, others would have to wait and would perhaps wait forever (Ferguson (1961, 310); Annals of Congress, II, 1308, 1340, 1366, 1387, 1490). Their suspicion was fed by the eagerness with which Massachusetts and South Carolina pushed for immediate assumption. Maryland, North Carolina and Georgia took a relatively forceful position against assumption. Pennsylvania, with a modest debt of two million dollars, took an ambivalent position. By contrast, New York, New Jersey, Massachusetts and South Carolina, all heavily in debt, strongly backed a transfer of liabilities to the Union. In fact, only one representative from New England voted against assumption.

In the EU, similar disputes occurred as the sovereign debt crisis escalated between 2010 and 2013. The prolonged economic crisis has created centrifugal forces that are pulling European public opinion apart. In present-day Europe, the embattled countries at the eurozone's periphery are in favour of debt assumption, while a number of northern countries, led by Germany, have opposed further steps toward debt mutualisation (Wearden, 2013). Germany, but also France under the leadership of Nicolas Sarkozy, had become the main opponents to debt mutualisation of any kind. Similar in economic weight to Virginia during the late 18th century US, Germany makes up roughly one fourth of the eurozone's population and contributes almost 30 percent to the eurozone's overall GDP. As in the US, the largest country saw itself in 
a position of being exposed to debt assumption claims; it was a number of comparatively small countries that were seeking the bailout. Greece, Ireland and Portugal, by contrast, account individually for less than five per cent of the eurozone GDP. Among the countries supporting assumption, the lone exception is Spain, which is the fourth largest state in the eurozone in terms of GDP.

The official position of each eurozone country on the issue of debt mutualisation was mirrored by domestic public opinion (Bechtel/Hainmueller/Margalit, 2012). Germany, the country that would be burdened with the largest share of costs in any mutualisation scheme, has shown the stiffest opposition to bailouts. ${ }^{5}$ At every step, the German government has engaged in heated negotiations with the other eurozone members, vigorously debating the conditionality that is to be attached to rescue efforts. ${ }^{6}$ Indeed, polls in Germany and France reveal strong opposition to bailouts, with only about one in three voters willing to support the rescue of other member states. ${ }^{7}$

We thus find strong parallels between the US in the 1790s and the Europe of today, particularly with regard to the initial array of political forces and their economic interests, which serve to define the battle lines of the debate. Generally, states support debt assumption when they are likely to benefit from mutualisation, and oppose it when they are likely to lose.

\section{Fairness and morality as rhetorical strategies}

Having outlined the lines of opposition between debtors and debt assumers, we find additional similarities between the US and present-day Europe with a view to the intentions and motives that accompany support for or opposition to debt assumption. A comparative analysis shows that the arguments related to fairness and morality are waged by states seeking assumption and by those rejecting it. When one side believes that an excessive debt burden has arisen because of undisciplined spending behaviour, and thus should not be assumed, this is ultimately an argument about fairness. Yet, fairness considerations also underlie the reverse case, when debt assumption is advocated by pointing to common causes for which all states within a union should be rightfully responsible. These arguments ultimately hinge on the just assignment of liability. While each state should generally be liable for its own budgetary policies, the argument that burdens should be externalized gains traction if high spending is made to the benefit of a common good (i.e., with external benefits) - in the latter case, the costs should be externalized. This perspective on when externalization is justified is supported by economic theory. If a state engages in spending that produces positive spillovers for other countries, these costs should generally be borne by all beneficiaries in accordance with the degree to

$5 \quad$ "Merkel bekommt Vorgaben für die Euro-Rettung; Koalitionsfraktionen im Bundestag wollen bei Verhandlungen in Brüssel mitreden", Die Welt, 02/24/2011; "Euro-Rettungsschirm: Am Ende des Tunnels", Frankfurter Allgemeine Zeitung, 09/25/2011.

$6 \quad$ See, for example, "Euro-Finanzminister beraten über Finanzhilfe", NZZ online, 06/19/2011.

7 "French People Oppose Second Greek Bailout, Ifop Poll Shows", Bloomberg News, 09/17/2011; "Germany Backs Greece Aid, but at a Cost to Merkel", New York Times, 02/27/2012. 
which they benefit. By contrast, where no positive spillovers exist and transfers only benefit the recipient state, moral hazard is engendered, i.e., the transfer creates incentives for the recipient country to rely on the transfer and externalize its individual costs.

In the US of the 1790s, claims about fairness as well as considerations of moral hazard were central in the debate on debt assumption. In at least three protracted debates in 1790 and 1791, opponents in Congress objected that the assumption of state debts would be unfair, as some states (such as Massachusetts and South Carolina) would be relieved of greater burdens than others (such as Virginia and North Carolina). Indeed, the severity of the debt problems faced by each state differed radically from state to state. While all states had debts from the war, they paid down this debt with varying degrees of speed. For example, the southern states (excluding South Carolina) had already paid off 83 percent of their debt. Consequently, some states saw in Hamilton's proposal a plan to alleviate the burden on those states that lagged behind in their debt payments, a move that would effectively punish the southern states for their greater efforts in achieving repayment (Elkins/McKitrick, 1993, p.120). Massachusetts and South Carolina had done little to pay their war debts and had much to gain from assumption. The assumption of state debt would relieve the states with high debt levels of the need to raise taxes (Wood, 2009, p. 96).

The strongest opponent to debt assumption was Virginia, the most populous state at that time with nearly 700,000 residents (Wood, 2009, p. 104). Containing one fifth of the nation's population and generating one third of its output, Virginia argued that it would be unfairly punished for its budgetary discipline, which had afforded a significant debt reduction. As Virginia saw it:

A large proportion of the debt thus contracted by this state has been already redeemed by the collection of heavy taxes levied on its citizens, and measures have been taken for the gradual payment of the balance, so as to afford the most certain prospect of extinguishing the whole at a period not very distant. But, by the operation of the aforesaid act, a heavy debt, and consequently heavy taxes, will be entailed on the citizens of this Commonwealth, from which they never can be relieved by all the efforts of the General Assembly whilst any part of the debts contracted by any state in the American Union, and so assumed, shall remain unpaid; ${ }^{8}$

But Virginia not only raised objections to servicing the debts of other states based on fairness. It also opposed assumption on the grounds that it was morally questionable, as it would reward bad behaviour. This argument was expressed in James Madison's and James Monroe's speeches in the House during the spring of 1790 . The assumption proposal did an injustice to

8 Virginia’s Remonstrance Against the Assumption of State Debts (16 December 1790) - Lance Banning, Liberty and Order: The First American Party Struggle (2004). 
the southern states by "compelling them, after having done their duty, to contribute to those states who have not equally done their duty” (Ellis, 2002, p. 57).

Numerous debates in Congress in 1790 and 1791 addressed the issue of assumption. James Jackson of Georgia was a vehement opponent of all of Hamilton's proposals. He argued that each state should be free to deal with outstanding debts based on the "convenience" of its inhabitants. Another opponent of assumption, Samuel Livermore of New Hampshire, objected to the enormous and unnecessary increase in federal debt. Payment ought to be left to the states, he said; they had "their peculiar modes of raising money" and could best adapt to the "habits and opinions" of their own citizens. ${ }^{9}$

The pro-debt assumption faction was led by Elbridge Gerry and Fisher Ames of Massachusetts and the two delegates from South Carolina, William Smith and Edanus Burke. They emphasized the wartime sacrifices of and current problems faced by their states, concluding invariably that they had incurred debts for the sake of the Union, and were therefore deserving of assistance in repayment (Ferguson, 1961, 313).

Similarly, the arguments for and against debt assumption during EU sovereign debt crisis have also been couched in terms of fairness and morality. Comparison to US history shows that Virginia's position in relation to the beneficiaries of debt assumption has strong parallels to Germany's position in relation to the European periphery. Mainstream German opinion holds that austerity measures are the best way to break the cycle of debt creation, reassure the private sector and promote real and sustainable growth. In the view of many Germans, the debt crisis in the eurozone's periphery is the result of overspending by irresponsible governments who exploited the lower interest rates obtained from entry into the Economic and Monetary Union (EMU) (for the following Dullien/Guerot, 2012, p.4).

A key feature of the dominant narrative in Germany - and to some extent in other countries, such as France (prior to the current administration under François Hollande), Finland and Slovakia ${ }^{10}$ - is the assertion of a divide between "irresponsible" governments at the eurozone's periphery, which have caused the crisis, and "responsible" governments at the eurozone's core, which are being asked to repay the debts. According to this line of argument, the GIIPSs (i.e., Greece, Italy, Ireland, Portugal and Spain) are responsible for the problems they face, and it is up to them to regain market confidence. In terms of solutions, this narrative asserts that fiscal retrenchment as well as labour market liberalization and welfare state reforms are all necessary. Furthermore, it is claimed that the "responsible" governments at the eurozone's core have a right to refuse bailout, as well as to insist on reforms. ${ }^{11}$

$9 \quad$ Annals of Congress, II, 1378-1380, 1353.

10 The opposition against debt mutualisation was thus not limited to Germany. Politicians in other nations (for example the former Finnish prime minister Katainen and the former French prime minister Sarkozy) also expressed their negative views on debt mutualisation. However, for the purpose of comparing with the US case (and the particular role of Virginia), the focus here lies on Germany.

11 Weidmann, 'Rebalancing Europe', speech at Chatham House in London, 28 March 2012: “The typical German position could be described as follows: the deficit countries must adjust. They must address their 
A fairness argument frequently voiced in Germany has been that Germany itself had to endure profound reforms at the beginning of the 21st century, reforms that ultimately transformed the proverbial "sick man of Europe" into the "New Wirtschaftswunder". ${ }^{12}$ These reforms increased labour market flexibility, rolled back the welfare state and were implemented against stiff opposition from unions and segments of civil society, as they were viewed as an effort to bolster German competitiveness on the backs of the working class. The difficulties faced in implementing these reforms have made the argument that no country should be spared the need to conduct reforms. ${ }^{13}$

Yet, arguments based on notions of fairness and morality have also been raised in Greece. First, it has been argued that the extension of credit is not purely for the benefit of Greece, but rather to safeguard the euro area as a whole, ensuring economic stability that ultimately favours the states assuming the debt. Furthermore, as the Greeks themselves have pointed out, the rescue packages are not designed to help the Greek populace, but rather to shore up Greece's financial sector (Eichengreen, 2010). Germany's banking sector heavily invested in Greece. Accordingly, Germany is an indirect beneficiary of the rescue packages, as they prevent German banks from suffering heavy losses.

Second, in terms of moral arguments, Greece has also made the claim that Germany still owes the country reparation payments for the occupation during World War II. The Greek newspaper To Vima, for example, published a headline titled "What Germany Owes Us". A Greek government commission arrived at a similarly clear conclusion: "Greecs never received any compensation, neither for the loans it was forced to provide to Germany nor for the damages it suffered during the war." In this vein, the Greek foreign minister, Dimitris Avramopoulos, told the parliament in Athens: "We will exhaust every means available to arrive at a settlement. One can't compare the times, but also one cannot erase the memories." (Inman, 2013).

The moral hazard argument is closely related to fairness considerations. According to this argument, bailing out a state reduces its incentives to pursue balanced budgets. In the US, the issue of moral hazard was voiced by opponents who feared that the mutualisation of debt would mean the indefinite prolonging of its repayment. Parallels were drawn to the burdens imposed by Great Britain's public debt, just as, for many years, the American colonies were taxed to support the debts of the colonial power (Bolles, 1969, p.32).

structural problems. They must reduce domestic demand. They must become more competitive and they must increase their exports."

12 By contrast, Germany was the first euro area member to breach the rules of the Stability and Growth Pact. One could argue that, based on the notion of fairness, this should lead Germany to allow for higher debt levels in order to implement reforms, or to implement debt mutualisation so that all member states are guaranteed to be sufficiently financed for their structural reforms.

13 The discussion has somehow lost its tension since the president of the ECB, Mario Draghi, announced the possibility to engage in outright market transactions, which has calmed markets. The imminent need of fully-fledged debt mutualisation disappeared. No further ESM assistance was provided to the euro area member states. 
Similarly, the spectre of moral hazard is also regularly cited in Germany, as many see the bailouts as disincentivizing governments on the eurozone's periphery from engaging in sound spending behaviour. Bailouts make continued overspending possible even after financial markets have imposed higher bond rates as punishment for irresponsible behaviour.

In both the US and Europe, the moral hazard argument also emerged in a legal context. The legal expression of the moral hazard argument is what we call today the "no bailout principle.” According to this principle, no country should be bailed out, as this would otherwise undermine incentives to maintain balanced budgets. In Europe, this principle is explicitly enshrined in the European treaties. In the US, there has never been an explicit no-bailout rule. However, Virginia did invoke the absence of a bailout provision in the Constitution:

During the whole discussion of the federal constitution by the convention of Virginia, your memorialists were taught to believe "that every power not granted, was retained"; under this impression, and upon this positive condition, declared in the instrument of ratification, the said Government was adopted by the people of this Commonwealth; but your memorialists can find no clause in the constitution authorizing Congress to assume debts of the states! [...] This provision is "that all debts contracted, and engagements entered into, before the adoption of this constitution, shall be as valid against the United States, under this constitution, as under the Confederation"; which amounts to a constitutional ratification of the contracts respecting the state debts in the situation in which they existed under the Confederation; and, resorting to that standard, there can be no doubt that, in the present question, the rights of states, as contracting parties with the United States, must be considered as sacred ${ }^{14}$

Virginia's argument concerning the absence of an explicit bailout provision is mirrored in contemporary Europe by the controversial legal debate on the interpretation of the bailout prohibition contained in European treaties. This provision has mostly been interpreted as strictly forbidding bailouts, in turn implying that various financial support measures undertaken to date are not permissible. Germany, in particular, has invoked the Maastricht Treaty's "no bailout" language when resisting the mutualisation of debt and Eurobonds. Many Germans have argued that a "debt community” would reduce political leverage for pushing through structural reforms, as well as increasing moral hazard within the EU.

Moreover, both in the US and euro area we find general concerns about the effects of assuming debt. In Congress, some individuals were opposed to any plans for issuing federal debt. A remarkable standpoint vis-à-vis the funding of debt can be found in the letters addressed to the US Yeomanry: "The uniformity and certainty of the evils arising from public credit and fund- 
ing systems, wherever introduced, manifest that we ought to attribute such evils to any mismanagement of the agents, but to consider them as the unavoidable consequence of violating those laws of nature which God has ordered to regulate men in society, which, therefore cannot be violated with impunity." 15 While certainly expressing less radical views, opponents of debt assumption in the euro area have argued in a similar vein. Particularly in Germany, greater budgetary discipline has been a frequent demand, and has manifested itself in strict austerity programs being imposed on recipient countries. Expenditure cuts and tax increases have thus been part of the conditionality attached to credit lines.

\section{The Issue of Speculation - "Good and Bad Creditors"}

Every act of assuming debt inherently involves an extension of protection to creditors. By shifting debt from one debtor to another or by sharing debt, creditor claims are upheld. Generally, for governments, there is no standard insolvency procedure for the orderly management of creditor claims. ${ }^{16}$ This is fundamentally different from private entities, which are - at least nowadays - subject to specific rules that generally lead to a loss for creditors who invested their money in an insolvent private enterprise. From an economic viewpoint, debt mutualisation, instead of forcing creditors to take losses, produces adverse incentives. It increases the inclination of creditors to purchase debt, because they factor in that debt assumption will occur, thereby reducing the risk of default and losses in their investment.

In addition to economic arguments, there is a strong moral issue related to protecting creditors. When creditors are generally protected from taking losses, this may raise the ire of states assuming debt. In both the US in the 1790s as well as in the current euro area sovereign debt crisis, we find heated debates surrounding the treatment of so-called "speculators," i.e., the creditors of US states or euro area countries. The crux of the moral concern is as follows: Why should private investors who willingly invested their money in securities be protected from the risk of default at the expense of taxpayers in the state that assumed the debts?

Hamilton sought to protect creditors. His proposal called for the issuance of new securities to those who presented the old certificates in exchange, with the bearer receiving the full value. The problem was that many original holders of the securities, mainly veterans of the American Revolution who had received them as pay for their service in the war, had then sold them at a fraction of their original value to "speculators" (Ellis, 2002, p.56). Hamilton's proposal would thus favour speculators who bought state debts prior to the creation of federal bonds. Madison was against the idea and proposed that, by issuing new federal securities, the Treas-

15 Letters addressed to the Yeomanry of US, p.23: Five letters, addressed to the yeomanry of the United States: containing some observations on the dangerous scheme of Governor Duer and Mr. Secretary Hamilton, to establish national manufactories.

16 Under present US rules, according to Chapter 9 of the US Bankruptcy Code, US municipalities can file for insolvency. However, this procedure does not apply to states. 
ury should devise a formula for dividing the proceeds between the original recipient of an outstanding debt certificate and its final holder.

The question on the treatment of "speculators" split the House, as many believed debt assumption would favour speculation (Elkins/McKitrick, 1993, p. 117). In the eyes of opponents, the debt assumption campaign was spearheaded by speculators who were maligned as merely interested in profit. Jefferson, for example, Secretary of State in Washington's cabinet, asserted that the "greedy members" of Congress who voted for assumption were acting out of self-interest. He chastised the selfish speculators who had snapped up at deep discounts most of the bonds that patriotic Americans had originally purchased to fund the Revolutionary War. Jefferson argued that the speculators would make tremendous profits if they received face value for the bonds, as Hamilton had proposed. Except for South Carolina, whose members favoured immediate assumption without any conditions, most southern delegates supported Madison's proposal to discriminate between original and final holders, and they controlled enough votes to prevent the enactment of the Hamiltonian plan (Bolles, 1969, p. 32).

Madison's proposal clearly ran counter to the terms explicitly printed on the securities as well as English contractual law. Hamilton waged vigorous objections, pointing to both law and precedent (Perkins, 1994, p.223). The Secretary of the Treasury expressed misgivings concerning how foreign investors might react to such a major departure from standard procedures. He thought it might dissuade Europeans from purchasing American securities in the future. Hamilton thought that any attempt to repudiate the debt or to distinguish between its original and current bearers would be not only unjust to those who had taken the risk purchasing the securities, but also ruinous to the standing of the young nation.

Some scholars have argued that Madison was disingenuous in calling for differential treatment of original and new bearers, and that he acted only out of concern for his political reputation in his home state of Virginia, where many constituents were angry about reports of ostensibly unchecked speculation in public securities in the late 1780s (Risjord/DenBoer, 1974, p.204). While Madison claimed that he was acting out of sympathy for the original bearers, this may have simply been an effort to appease his critics, rivals and constituents back in Virginia (Perkins, 1994, pp. 222, 394).

There has also been heated discussion in the present-day EU concerning the treatment of speculators. Burden-sharing among countries, but also the distribution of the losses between private investors and the public, has been among the proposals for a coordinated response to the debt crisis. To reduce the financial burdens falling on taxpayers, donor governments have required investors holding bonds of over-indebted countries to take a partial loss, or "haircut", on Greek debt. ${ }^{17}$ The level of loss to be absorbed by investors became a central issue in the

17 "True Finns threaten EFSF expansion, ESM solution uncertain", EuroWeek, 03/25/2011; "Merkel verlangt mehr Einsatz von den Deutschen", Spiegel Online, 05/22/2011. 
Greek bailout. ${ }^{18}$ The German Social Democrats and Green parties announced that they would approve the extension of credit to Greece in the German Bundestag, but only if private investors were required to take losses and a financial transaction tax was introduced. ${ }^{19}$ Imposing a "haircut" on private creditors who had lent to Greece was a simplistic and partly populist measure aimed at forcing "greedy private investors" to face part of the adjustment burden (Welfens, 2011, p. 21). Finally, policymakers called on private actors to accept a "haircut" of 21 per cent before the European bailout fund would make any further payments to Greece. This number was later revised to 50 per cent and eventually to over 90 per cent (Bechtel/Hainmueller/Margalit, 2012, p. 11).

We thus find that, in both the US and Europe, there were widespread calls to rein in or discipline "greedy speculators". Speculators were perceived as the beneficiaries of debt assumption and were maligned for benefiting unjustly while others suffered. Calls for speculators to share burdens clearly have a populist dimension. However, those carrying responsibility in government (Hamilton in the US, Angela Merkel in Germany) have been wary of populist calls to punish speculators, acutely aware of the risks involved, including a possibly chilling effect on future investment. For Hamilton, the potentially negative reaction of foreign investors led him to resist popular calls for greater creditor liability.

\section{Imposing Conditionality}

In light of the diverging interests and views on debt assumption, it appears natural that any bargaining would ultimately produce outcomes that involve compromises and conditions. Generally, we can say that countries are able to obtain concessions and ensure reciprocity, depending on their bargaining power. Reciprocity may take various forms, as the experience with debt assumption in the US and the euro area shows. First, during negotiations, bargaining efforts generally focus on limiting or expanding the scope of debt assumption, depending on each state's individual interests. Second, conditions may be imposed in order to maximize the probability that debts will be repaid or future debt assumption avoided. Third, conditions that are unrelated to the debt issue may be imposed within the scope of reciprocal bargaining.

In the US, the opponents of debt assumption initially directed their efforts at a complete rejection of debt assumption, and later on minimizing the size of the debt to be assumed. The division of opinion on debt assumption is clearly reflected in the arguments waged between Jefferson and Hamilton. Jefferson was worried about the cost of assumption, and about Hamilton's political intentions. To Jefferson, assumption threatened the republic by dangerously centralizing financial power. Madison agreed with Jefferson, and in April 1790 they were able

18 In fact, losses have been imposed on the private sector on two occasions; first, in the context of the Greek Private Sector Involvement (PSI) programme in February 2012, and then the context of the Cyprus financial rescue programme in February 2013. These involvements of private creditors may have far-reaching implications for any future debt settlement. The absence of clear rules on "haircuts" for private creditors is a de-stabilizing factor and increases volatility of market reactions.

"Bundestag zu Hilfe für Griechenland bereit", Sueddeutsche Zeitung, 04/27/2010. 
to defeat assumption when it first came up for vote in the House of Representatives. By July, however, Madison and Jefferson had softened their opposition. For one thing, Hamilton had reduced the scope of assumption to $\$ 21.5$ million, and had agreed to adjust accounts so that Virginia's net payments to the federal government would be zero. Hamilton had initially proposed taking over all existing state debts, which he estimated at \$25 million. However, when opposition arose in the House, Hamilton tabled a compromise that restricted assumption to specific amounts - in each case less than the actual debts of each state. Only the intervention of Jefferson, at the request of Hamilton, finally resolved the impasse (Ferguson, 1961, p. 321).

Another form of conditionality in the compromises of 1790 had to do with the settlement of amounts owed between states. The opponents urged that assumption should go hand in hand with a settlement of accounts, and even then could be justified only by coupling it with an arrangement that would give states that had paid their debts the fullest credit in the final settlement. ${ }^{20}$ The idea was that the federal government would assume state debts and subsequently charge the states accordingly through accounts that were to be settled in order to equalize the per-capita costs of financing the Revolutionary War. The flaw of the deal was that in theory no state could either gain or lose from assumption, for it was to be subordinate to a final settlement of the accounts of the Union. The debts that a state was relieved of in 1790 would be charged against it in the final settlement (Ferguson, 1961, p.308).

From the very beginning there had been an understanding, written into the Articles of Confederation, that the costs of the Revolution were to be borne by the United States as a national government and not by the states acting individually. In practice, the financing of the war effort had to be accomplished by loans and by contributions from the states to the "common charges". Congressional approval was required to designate expenditures as the "common charges". Yet the determination of "common charges” (i.e. "good debts”) was difficult. The line between expenditure authorized by the Continental Congress and those not so authorized could not be maintained clearly. Many states had either failed to keep proper records on the size of their expenditures, and the mode of financing them had varied considerably from state to state. Moreover, Virginia had paid off a large part of its debts. Ideally, there ought to have been a way to settle all these difficulties equitably. A General Board had the task of adding up the expenditures of the states, after eliminating those that could not be considered authorized. The Board, set up in 1787, sought to determine on a case by case basis the amount contributed to the "common charges" based on documentary evidence provided by the states.

While the debate on the settlement of state accounts and the determination of "common charges" focused on the amount of debt assumption, the most famous bargain took place on the location of the future capital. Since debt assumption remained controversial until the very end, the issue on where to locate the new capital was finally made part of the bargain. Hamilton agreed to support moving the nation's capital from New York to the banks of the Potomac River in Virginia after a ten-year interim period in Philadelphia. Madison and Jefferson hoped 
the move would stimulate economic development in their state, weaken the ties that Hamilton sought to promote between the federal government and the financial elites of New York and Philadelphia, as well as increasing Virginia's influence over the government (Ferguson, 1961, pp.319). Ever since Congress had left Philadelphia in 1783, Virginia had been advocating for moving the capital to the Potomac. Finally, Virginia prevailed in the effort to move the permanent capital to Virginia. Pennsylvania got the temporary capital for Philadelphia. The trade gave Virginia a benefit that this state could not otherwise have won, probably averting a complete defeat on the issue (Ferguson, 1961, p.320).

In the EU, conditionality has also been attached to debt assumption, although the nature of the conditionality differs from the US historical case. The conditionality attached to the bailouts has generally aimed at changing the economic policies in the countries whose debt is assumed. The idea behind this type of conditionality is to maximize the likelihood that loans will be repaid to the countries taking on the debt. To this end, a wide range of policy measures have been dictated, which, in practical terms, has meant a partial surrender of national sovereignty.

A major dimension in the debate surrounding the eurozone's response to the debt crisis has been the conditions to be imposed on the recipients of bailouts. From early on in the negotiations with debtor countries, major donors including Germany made it clear that any bailout assistance would only be provided with strict conditions. ${ }^{21}$ In Greece, for example, comprehensive conditionality aimed at reforming the Greek economy has been imposed. ${ }^{22}$ Tax increases and expenditure cuts are the core aspects of this conditionality, and are directed at achieving budget consolidation. Yet additional measures aim to reform Greece's labor market, especially the wage-setting process, in order to encourage greater wage flexibility. The ascendant conditionality and austerity doctrine was largely attributable to German influence (for the following Dullien/Guerot, 2012, p.4).

Even though conditionality imposed by donor countries has been crucial, this does not mean that there was no basis other than serving the financial interests of the creditor countries. In fact, the economic adjustment programmes implemented in the crisis-ridden eurozone countries have a strong theoretical underpinning (Arghryou, 2014). In addition, the policies implemented in the context of conditionality have been (at least to the present point) endorsed by the electorates of the crisis countries (despite the occasional heavy riots against the measures). Greece, Ireland, Portugal and Spain are all run by governments that had committed prior to their election to implement economic policies consistent with the conditionality clauses of the financial support these countries received from their international lenders. Thus, one might plausibly argue that the present policies implemented in these countries are not exclusively the result of conditionality externally imposed by creditor countries in return for financial assistance, but also reflect a shift of preferences within these countries towards macro-policies,

21 "Germany Once More on Defensive in Eurozone", International Herald Tribune, 5 May 2012.

22 Greece: memorandum of understanding on specific economic policy conditionality, 2 May 2010, available at http://ec.europa.eu/economy_finance/publications/occasional_paper/2010/op61_en.htm. 
which deliver more sustainable outcomes in comparison to the policies implemented in the recent past.

In contrast to the present-day EU, the US states' sovereignty was preserved entirely, as debtor states were not subject to individual conditions or restrictions to their domestic policies. However, new federal powers to impose levies and collect customs duties meant that some authorities migrated from the state to the federal level. Clearly, Hamilton's funding and assumption plan required a steady flow of federal income, and in an age when resentment ran high against all forms of taxation, governments had few reliable sources of revenue. Hamilton knew that the government funding for his assumption plan would depend to a large extent on customs duties. Since the vast majority of imports came to America from the United Kingdom, Madison's plan to impose levies on British goods threatened Hamilton's entire system (Schwarz, 20087). For in the end, if the British retaliated in kind, trade would slow, this would lead customs revenues to dry up, and where would Hamilton find the funding for his plan?

The Constitution sought drastically to reduce the power of the states. Article I, Section 10, among others, forbid the states from levying tariffs or duties on imports or exports, banning them from issuing paper money or bills of credit (Wood, 2009, p.97). On 4 July 1789, before Congress created the Treasury, President Washington signed into law a tariff act designed to generate income for the new government. The act established a complex set of duties on imports, rebates for re-exported goods and special terms for imports carried by American ships. The act generated more than \$1 million per year, but this was far less than the \$3 million that Hamilton estimated would be needed to make interest payments to the holders of federal debt. Therefore, in January 1790, in his "Report on the Public Credit", Hamilton recommended an increase in tariffs and the introduction of internal taxation in the form of an excise tax on distilled spirits. However, he stopped short of proposing direct taxes (i.e., poll and property taxes). He was concerned that these taxes would be met with popular hostility, and he wanted to promote state cooperation with his financial program by leaving direct taxation in the hands of state and local governments.

However, in both cases in which fiscal powers migrated upward in the US and Europe, the effect was to ensure that debts would be repaid. In the US, the new fiscal powers at the federal level were necessary to provide the financial means to pay off the debts. And in the EU, the (temporary) surrender of economic policy to creditor states while being on conditional support programs has been implemented to satisfy creditors' concerns about the repayment of debts and to create an economic environment that reduces the risk of loss.

\section{Conclusions}

There have been two major incidents of debt mutualisation within a single-currency area. Notwithstanding differences in the causes and evolution of debt mutualisation processes, these incidents share commonalities with regard to the behavioural pattern of the involved 
stakeholders. Debt assumption usually follows intense bargaining between debtor states and those states assuming their debt; deals are made and conditions are imposed. Not surprisingly, there is a split between countries benefiting from debt assumption and those that must bear its costs. In both the US and the EU, we see a north-south divide in this regard, whereby paying countries reject and receiving countries support debt assumption.

This study aimed to identify the commonalities between two historical cases of debt assumption from the perspective of political economy by comparing stakeholders' interests and attitudes toward debt assumption. A key commonality identified in this study is the use of fairness considerations as a basis for requesting or opposing debt mutualisation. Appeals to fairness made by those opposing assumption may take various forms and may include blaming debtor states for not having done their duty to rein in spending, for not having implemented reforms to improve competitiveness, as well as for manipulating statistical data. Generally, countries that are to assume debt tend to advocate individual responsibility, according to which each state should be responsible for its own matters. Fears of moral hazard, which stress the adverse incentives resulting from debt assumption, can be seen in both the US and Europe, and represent an additional strand of the fairness argument. On both occasions, we encounter the legal claim that debt assumption is constitutionally prohibited. By contrast, proponents of debt mutualisation typically argue that debts should be borne by all states, as they constitute a public burden or common good. They also argue that sharing the debt is imperative due to economic interdependencies and spillovers that would benefit the states assuming the debt.

As debt assumption is an emotional issue led by moral considerations, forcing creditors to share in the burden of restructuring appears not only economically justified, but also reasonable from an ethical perspective. In this connection, commonalities can be seen in both historical incidents regarding the depreciative and populist language again "speculators" who should be "forced" to take losses.

Finally, bargaining is a prominent feature in both cases of debt assumption. Bargaining usually leads to a set of conditions for debt assumption, which ensure reciprocity in the deal. Bargaining efforts are typically directed towards limiting or expanding the scope of debt assumption, depending on each side's interests. This may involve threats to assume merely part of the debt or impose ceilings on debt assumption. Conditionality may also be used to increase the chance that debts will be repaid and future debt assumption avoided. This may involve farreaching intrusion into a nation's sovereignty, with national policies set by external stakeholders or - as in the US - fiscal competencies being shifted to the federal level to ensure debt repayment. Moreover, conditions may be imposed that are unrelated to the debt issue as a means of reciprocal trade. In this case, debt assumption may be just one item in a more comprehensive list of concessions.

Notwithstanding the focus on communalities between the American past and the European present, the obvious differences between the two incidents of debt assumption should not be 
neglected. First, the legal and political basis in the two situations has been very different. In the US, the circumstances were determined to a large extent by the move towards uniting the states. By contrast, in Europe there is currently no strong political will to strive for a "United States of Europe" with less power on a national level and a common European budget. Rather, the crisis has led to a move of disintegration and voices in favour of more decentralization have been raised. Second, debt brakes in the US were introduced on a voluntary basis, while in some countries in the euro area they have been imposed as a part of the austerity logic of counter-crisis measures. Third, the bargains at stake were different. In the US, the central government assumed the state's debt, and in exchange it received a new central source of funding (tariff revenue). In the euro area, the situation is different to the extent that the euro area has no budget and the EU budget is very small compared to the US budget. On top, the EU budget is mainly funded through transfers from some member states to others and not by a central authority with an own budget, as it is the case in the US. Finally, the stakes were different: in the US case, the discussion surrounding debt mutualisation had an impact on the unity of the United States, while in economic terms states like Virginia had little to lose in case a settlement would have failed. By contrast, in the European context the existence of the common currency has been at stake which had a direct effect on the economic interests of all countries including Germany as the country bearing the largest share of costs in any mutualisation and benefiting significantly from the common currency.

However, despite these obvious differences between the two cases, we have demonstrated considerable similarities from a political economy perspective. Two years after debt assumption Jefferson told Washington that the bargain made that evening with Hamilton was the greatest political mistake of his life, which stands in stark contrast to his initial view that Virginia had achieved a victory (Ellis, 2002, p.51). History will show whether this disappointment will also have a parallel episode in Europe's present-day crisis. There are certainly plausible historical reasons not to view the US experience as a good example for Europe. The continuation of the US history made visible possible moral hazard implications resulting from the US states' reliance on the federal levels debt assumption. US states increased their debt levels since the mid-1820s, mainly due to heavy investments in infrastructure creating a bubble that finally burst in 1837 (Sinn, 2014, pp.322). The federal level intervened for some time, buying up a great deal of the states' bonds, but finally pursuing a strict no-bailout policy. The consequence was the filing of bankruptcy of nine of the twenty-nine states. This suggests that uncertainty about (no-)bailout (in combination with reliance on past debt mutualisation) creates moral hazard. 


\section{References}

Alessi, C. (2013), 'The Eurozone in Crisis, Council on Foreign Relations', available at "http://www.cfr.org/" http://www.cfr.org/.

Arghyrou, M.G. (2014). Is Greece turning the corner? A theory-based assessment of recent Greek macro-policy. CESifo Working Paper 4995.

Bayoumi, T., P. Masson (1995), 'Fiscal Flows in the United States and Canada: Lessons for Monetary Union in Europe', European Economic Review 39, pp. 253-274.

Bechtel, M., Hainmueller, J. and Margalit, Y. (2012), 'Studying Public Opinion on Multidimensional Policies: The Case of the Eurozone Bailouts', October 1, 2012, MIT Political Science Department Research Paper No. 2012-27.

Bellofiore, R., Garibaldo, F. and Halevi, J. (2011), 'The Global Crisis and the Crisis of European Neomercantilism', in: Panitch, L, Albo, G. and Chibber, V. (eds), Socialist Register 2011: 10 The Crisis This Time, Merlin Press.

Bolles, A. (1969), 'The Financial History of the United States', Vol. II, Sentry Press, New York.

Bordo, M., Markiewicz, A. and Jonung L. (2011), 'A Fiscal Union for the Euro: Some Lessons from History', NBER Working Papers 17380, National Bureau of Economic Research.

Bordo MD, Jonung L, Markiewcz A (2011) Does the Euro need a Fiscal Union?; Some Lessons from History. In: Wood GE (Hrsg) Monetary and Banking History: Essays in Honour of Forrest Capie. Routledge, London [a.o.], P 195-234.

Bordo MD, James H (2008) A Long Term Perspective on the Euro. NBER Working Paper Series.

Chernow, R. (2004), 'Alexander Hamilton', The Penguin Press, New York.

Darvas Z (2010) Fiscal Federalism in Crisis: Lessons for Europe from the US. Bruegel Policy Contribution.

Dullien, S., Guerot, U. (2012), 'The Long Shadow of Ordoliberalism: Germany's Approach to the Euro Crisis', European Council on Foreign Relations, ECFR/49, February 2012.

Edling, M., Kaplanoff, M. (2004), 'Alexander Hamilton’s Fiscal Reform: Transforming the Structure of Taxation in the Early republic', The William and Mary Quarterly 61, 712. 
EEAG (2013), 'The EEAG Report on the European Economy, “US Precedents for Europe”', CESifo, Munich 2013, p.95-107.

Eichengreen, B., “Ireland’s Reparations Burden”, Institute for New Economic Thinking, 3 December 2010

Ellis, J. (2002), 'Founding Brothers', Faber \& Faber.

Elkins, S., McKitrick, E. (1993), 'The Age of Federalism, The Early American Republic, 1788-1800', Oxford University Press.

Ferguson. J. (1961), 'The Power of the Purse', University of North Carolina Press.

Henning, C., Kessler, M. (2012), 'Fiscal Federalism: US History for Architects of Europe's Fiscal Union', Peter Institute for International Economics, Workings Paper Series, WP 12-1, January 2012.

Inman, P., “Greece is right to expose German loans hypocrisy”, The Guardian, 26 April 2013.

Perkins, E. (1994), 'American Public Finance and Financial Services 1700-1815', Ohio State University Press.

Risjord, N., DenBoer, G. (1974), 'Evolution of Parties. Organization of American Historians', Bloomington.

Sargent, T. (2012), 'United States Then, Europe Now', Journal of Political Economy, Vol. 120/1, p. 13.

Schwarz, M. (2007), 'The Great Divergence Reconsidered: Hamilton, Madison, and U.S.British Relations', 1783-89, Journal of the Early Republic 27:3 (2007): 407-436.

Sinn, H.W. (2014). The Euro Trap: On Bursting Bubbles, Budgets and Beliefs. Oxford University Press.

Sylla, R. (2011), 'Financial Foundations: Public Credit, the National Bank, and Securities Markets', in: Douglas A. Irwin / Richard Sylla (eds.), Founding Choices, University of Chicago Press.

Wearden, Europeans Disillusioned and Divided by Debt Crisis, Survey Finds, The Guardian, 14 May 2013.

Welfens, P. (2011), 'From Greece to the U.S.: Financial Crises, National Debt, and their Consequences for Europe and the U.S.', Paper prepared for the AICGS/BIGS Workshop 
Wibbels, E. (2003), 'Bailouts, Budget Constraints, and Leviathans: Comparative federalism and lessons from the early United States', Comparative Political Studies 36 (June), 475-508.

Wood, G. (2009), 'Empire of Liberty, A History of the Early Republic', 1789-1815', Oxford University Press. 